\title{
Behavioural responses of indigenous benthic invertebrates (Echinogammarus meridionalis, Hydropsyche pellucidula and Choroterpes picteti) to a pulse of Acid Mine Drainage: A laboratorial study
}

\author{
Joaquim A. Macedo-Sousa ${ }^{\mathrm{a}, *}$, Almut Gerhardt ${ }^{\mathrm{a}}$, Christopher M.A. Brett ${ }^{\mathrm{b}}$, António J.A. Nogueira ${ }^{\mathrm{a}}$, \\ Amadeu M.V.M. Soares ${ }^{\text {a }}$ \\ ${ }^{a}$ CESAM and Department of Biology, University of Aveiro, Campus de Santiago, 3810-193 Aveiro, Portugal \\ ${ }^{\mathrm{b}}$ Department of Chemistry, University of Coimbra, 3004-535 Coimbra, Portugal
}

Behavioural responses of aquatic invertebrates may be used to detect spikes of Acid Mine Drainage.

\section{A R T I C L E I N F O}

\section{Article history:}

Received 6 November 2007

Received in revised form 7 April 2008

Accepted 3 May 2008

Available online $\mathrm{xxx}$

\section{Keywords:}

Online biomonitoring

Behaviour

Acid Mine Drainage

Toxicity discrimination

Aquatic invertebrates

\begin{abstract}
A B S T R A C T
The drainage of abandoned mines leads to several ecological problems, particularly the acidification of surface freshwater systems and heavy metal contamination. In order to study the possibility of using the behavioural early warning responses of Portuguese indigenous benthic invertebrates to detect an acute short-term pulse of Acid Mine Drainage (AMD), experiments with the Multispecies Freshwater Biomonitor MFB ${ }^{\mathrm{TM}}$ were performed and locomotion and ventilation were measured as endpoints. AMD was collected from the "São Domingos" mine (Southeast Portugal) and the following species were selected: Echinogammarus meridionalis (Pinkster, 1973), Hydropsyche pellucidula (Curtis, 1834) and Choroterpes picteti (Eaton, 1870). For simulating the pulsed exposure, AMD was added to river water where invertebrates were collected and $\mathrm{pH}$ was lowered until reaching 3.5. The effects of $\mathrm{H}^{+}$and heavy metals were discriminated using $\mathrm{HCl}$ positive controls. In addition to behaviour, mortality was registered. $E$. meridionalis was the most sensitive species in terms of mortality and behavioural endpoints, followed by C. picteti and H. pellucidula. E. meridionalis early warning responses consisted of increased locomotion with subsequent increase in ventilation, whereas for $C$. picteti only an increase in locomotion was observed. $H$. pellucidula showed no early warning responses. This work demonstrates the suitableness of using benthic invertebrates' behavioural early warning responses for detecting spikes of pollutants like AMD.
\end{abstract}

(c) 2008 Elsevier Ltd. All rights reserved.

\section{Introduction}

As a result of mining activities, previously buried material is exposed to weathering, since economically recoverable metals frequently occur as ore-bodies of concentrated metal sulphides (most commonly pyrite). Pyrite ( $\mathrm{Fe}_{2} \mathrm{~S}$ - iron sulphide) is oxidized in the presence of water, producing iron and sulphuric acid. Ferric iron, when discharged to surface water, hydrolyzes to produce hydrated iron oxide thereby the solution gets more acidic. Metals released from mine tailings in solution with the mine's acidic effluent form the Acid Mine Drainage (AMD) which may adversely impact the surface water due to its chemical nature (Earle and Callaghan, 1998).

\footnotetext{
* Corresponding author. Tel.: +351 234370 350; fax: +351 234372587.

E-mail address: jamsousa@ua.pt (J.A. Macedo-Sousa).
}

$\mathrm{pH}$ is a major factor determining metal toxicity. Some metals may compete with $\mathrm{H}^{+}$at binding sites, reducing their uptake and toxicity, while the toxicity of other metals may increase in the presence of high $\mathrm{H}^{+}$concentrations, probably due to changes in their speciation, mobility and bioavailability (Cummins, 1993). In addition, the uptake of one metal by the organism is dependent on several factors, e.g. the nature of the membrane where the uptake takes place, the presence of complexing agents in the water, or the developmental state of the organism. Therefore, metals' bioavailability and concomitant toxicity to benthic invertebrates may be considered species specific (Gerhardt, 1992). Metals when in toxic concentrations may act as metabolic poisons (Earle and Callaghan, 1998) or having several other modes of action (e.g. inactivation of enzymes) that in general have reflexes on important biological processes such as growth, reproduction or oxygen consumption (Depledge et al., 1993). However, the $\mathrm{H}^{+}$ions themselves exert adverse effects (Cummins, 1993), affecting several physiological functions such as $\mathrm{Na}^{+}$regulation, respiration, $\mathrm{Ca}^{2+}$ 
regulation and acid-base balance (Havas, 1981). These toxicological implications at the individual level may affect higher levels of organization. This is why acidic freshwaters normally have fewer species and a lower abundance and biomass of macroinvertebrates than circumneutral pH waters (Økland and Økland, 1986; Herrmann, 1990).

Benthic invertebrates are a useful tool in monitoring acidification since they show a high range of tolerance to different degrees of acidity (Fjellheim and Raddum, 1990) and may therefore be used as non-destructive environmental biomonitors. Moreover, they have the advantage of integrating water quality, taking into account the whole mixture of toxicants and reflect the effects of metal bioavailability on whole-body physiological responses. Biomonitoring also permits the detection of peaks of pollution that often cannot be detected because of concentrations below the detection limit of analytical methods for chemical monitoring (Gerhardt, 1995c). After the Sandoz accident at River Rhine in 1986, routine biomonitoring has increased in Europe in order to control, signal and predict calamities and accidental spills thus contributing to effective environmental management (Gerhardt, 2000a). As mentioned by Gerhardt (2000b) several continuous and semicontinuous biomonitors for water quality control have been used or are under recent development, based on the responses of different taxa, from bacteria to fish.

The presence of a stressor, such as freshwater acidification, often produces changes in the behaviour of macroinvertebrates that, when possible to observe and quantify, has the potential to be used as a biomarker in the assessment of stress. Behavioural responses are considered to be rapid and the first line of defence to environmental stimuli (Beitinger, 1990; Beitinger and McCauley, 1990). Hence, being one of the most sensitive indicators of chemical stress (Gerhardt et al., 1994; Gerhardt, 1996), behavioural responses can address the main aim of active biomonitoring, which is to detect pollution situations by use of early stress responses of sensitive test organisms (Gerhardt, 1995a).

The objective of this study was to test the sensitivity and response of three species of Portuguese indigenous benthic invertebrates, with different life history strategies and habitat selection and belonging to different trophic levels, to a short-term pulse of AMD. The test species were: Echinogammarus meridionalis (Pinkster, 1973), Hydropsyche pellucidula (Curtis, 1834) and Choroterpes picteti (Eaton, 1870). It was hypothesized that the presence of chemical stressors would elicit behavioural early warning responses in the test organisms, namely changes in locomotion and ventilation activities. The effects of low $\mathrm{pH}$ and metals were also discriminated and assessed.

\section{Methodology}

\subsection{Test species}

The three test species were selected in accordance with the following criteria: abundant in the water body from where they were collected (Persoone and Janssen, 1993); easily maintained in the laboratory (Lagadic and Caquet, 1998); belonging to a widely distributed group (Patrick and Boyer, 1994); and existence of previous lab trials where specimens from the same family revealed sensitivity to the effect of acidity and dissolved metals. In addition, the three selected species should, if possible, have different life history strategies, different habitat selection and belong to different trophic levels, so that different thresholds of toxic effects and reaction times to the toxic spikes with a relatively wide range of tolerances to AMD could be obtained. Another important aspect was that previous trials with the MFB ${ }^{\mathrm{TM}}$ had shown the possibility of measuring the organisms' behaviour thus proving the suitableness of these test chambers for Gammaridae, Hydropsyche sp. (Gerhardt, 1996) and C. picteti (Gerhardt et al., 2005a).

Based on the above-mentioned criteria a crustacean species - E meridionalis and two insect larvae species - H. pellucidula and C. picteti - were selected and collected from the field during late summer and early autumn (September-October). These groups are functionally the most important intermediate converters of living as well as dead biomass (Persoone and Janssen, 1993).
E. meridionalis (Pinkster, 1973) is an Amphipod from the family Gammaridae. This species, as a shredder, feeds directly on coarse particulate organic matter Specimens were collected in the River Lena (N $38^{\circ} 35^{\prime} 28.3^{\prime \prime}$, W $8^{\circ} 40^{\prime} 30.2^{\prime \prime}$ ), $\mathrm{pH} 8.2-$ 8.4, near Porto-de-Mós, characterized by a slow current with gravel substrate and large quantities of detritus (e.g. leaf material) retained in macrophyte beds. Other Gammaridae such as Gammarus pulex (e.g. Maltby et al., 1990; Taylor et al., 1994; Gerhardt, 1995c; Gerhardt et al., 1998; Gerhardt et al., 2003) have been widely used in monitoring tests, and a species from the same genus, Echinogammarus tibaldi (Pink. and Stock) was reported in articles for toxicity tests (e.g. Pantani et al., 1997) However, to our knowledge, no previous work with E. meridionalis had been done.

The Trichoptera $H$. pellucidula (Curtis, 1834) belongs to the Hydropsychidae, a widely distributed and often very abundant family (Statzner and Bretschko, 1998). H. pellucidula are collector-filter feeders (Pontasch and Cairns, 1991) that build nets to filter the fine particulate organic matter that they feed upon. The organisms were collected from the stones in a riffle of River Ceira ( $40^{\circ} 10^{\prime} 1.2^{\prime \prime}$, W $8^{\circ} 17^{\prime} 31.2^{\prime \prime}$ ), pH 7.4-7.7, near Coimbra. Several ecotoxicological studies have been reported to the genus Hydropsyche including behavioural responses to metals (Vuori, 1993; van der Geest et al., 1999).

C. picteti (Eaton, 1870) are Leptophlebiidae, one of the most diversified, oldest and largest families in number of species and genera within the Ephemeroptera (Peters, 1988). This species is a collector-gatherer (Palmer et al., 1996) that feeds on fine particulate organic matter. It was collected under the stones of a pool of River Vascão ( $\mathrm{N} 37^{\circ} 30^{\prime} 57.6^{\prime \prime}, \mathrm{W} 1^{\circ} 33^{\prime} 18.3^{\prime \prime}$ ), $\mathrm{pH}$ 8.0, near Mértola. A wide range of response to acid effluents with dissolved metals can be observed in Leptophlebiidae (Taylor et al., 1991; Gerhardt, 1993, 1995b).

\subsection{Test solutions}

The AMD was obtained in the Mine of S. Domingos, southeast of Portugal ( $37^{\circ} 39^{\prime} 56^{\prime \prime}$, W $7^{\circ} 28^{\prime \prime} 46^{\prime \prime}$ ), near Beja, a copper-pyrite mine abandoned since 1965. Although abandoned, it is still responsible for impacts in its surrounding environment as a continuous source of water pollution with the AMD's ranging from $\mathrm{pH} 2$ to 4. Owing to its effluents, the Mine of S. Domingos constitutes a chemical hotspot whose dispersion and intensity should not be overlooked (Oliveira, 1997; Lopes et al., 1999).

Three samples of AMD at $\mathrm{pH}=2.6$ were collected and analyzed by both "Inductively Coupled Plasma Atomic Emission Spectroscopy" (ICP-AES) and "Inductively Coupled Plasma Mass Spectrometry" (ICP-MS) (Table 1). When the values were less than $30 \mathrm{\mu g} \mathrm{l}^{-1}$ the results from ICP-MS were used. In Table 1 there are also the results from the waters of the rivers where the test species were collected that were analyzed with the same equipment described above.

\subsection{Multispecies Freshwater Biomonitor (MFB $\left.{ }^{\mathrm{TM}}\right)$}

For the assessment of the AMD effects, different behaviour patterns of aquatic organisms, were measured and analyzed with the MFB ${ }^{\mathrm{TM}}$. The MFB ${ }^{\mathrm{TM}}$ is based on the quadropole impedance technique (Gerhardt et al., 1994, 1998) where one pair of electrodes generates a high frequency alternating current perturbation and the other pair measures changes of the impedance and its frequency within the chamber, due to the organisms' movements (Gerhardt, 2000b). The chambers are made of plexiglas pipe ( $2 \mathrm{~cm}$ in diameter and $4 \mathrm{~cm}$ long), with the stainless steel electrodes attached oppositely to the inner walls, and are capped with $1 \mathrm{~mm}$ mesh in both ends. 'The chambers are connected to the MFB measuring device, where the result of the organisms' activity is registered and subsequently transferred to a personal computer. The data are plotted in a current vs. time graph with a specific software and are transformed into a frequency histogram by a Fast Fourier Transformation with the Haming function (Gerhardt et al., 1998). The frequency histogram includes the relative amounts of the low frequency behaviour $(0-4 \mathrm{~Hz})$ - slow movements such as locomotion - and high frequency behaviour $(4-8 \mathrm{~Hz})$ - ventilation - (Gerhardt, 2001) that can be integrated over time giving us two bands that represent the percentage of frequency of each type of behaviour.

\subsection{Simulation of short-term acid pulses}

The organisms were acclimated in the laboratory for at least 2 days in aerated aquaria $\left(>90 \% \mathrm{O}_{2}\right.$ ) with water collected from their natural environment and fed ad libitum with fragments of dried alder leaves once every 2 days. Conditions in the laboratory were as follows: temperature of $20 \pm 2{ }^{\circ} \mathrm{C}$, and a $16 / 8$ light-dark cycle (08:00-23:59 light/00:00-07:59 dark).

A MFB $^{\mathrm{TM}}$ with 48 channels and accordingly 48 chambers was used; organisms were tested individually to get as many replicates as possible. Individual specimens were deployed for ca $40 \mathrm{~h}$ in MFB ${ }^{\mathrm{TM}}$ chambers; 24 chambers were allocated as treatment replicates and the other 24 as the control replicates. The chambers were put in trays and immersed in water from the organisms' natural environment but treatment and control replicate were set in different trays. Water was pumped, with a Watson-Marlow peristaltic pump at $90 \mathrm{rpm}$, to a bucket where the medium was aerated and re-circulated again to the trays (Fig. 1). Aeration provided high levels of dissolved oxygen (>90\%) during the test.

To simulate short-term acid pulses, a high concentration of AMD was used because it is important to consider high doses in toxicology experiments to provide 

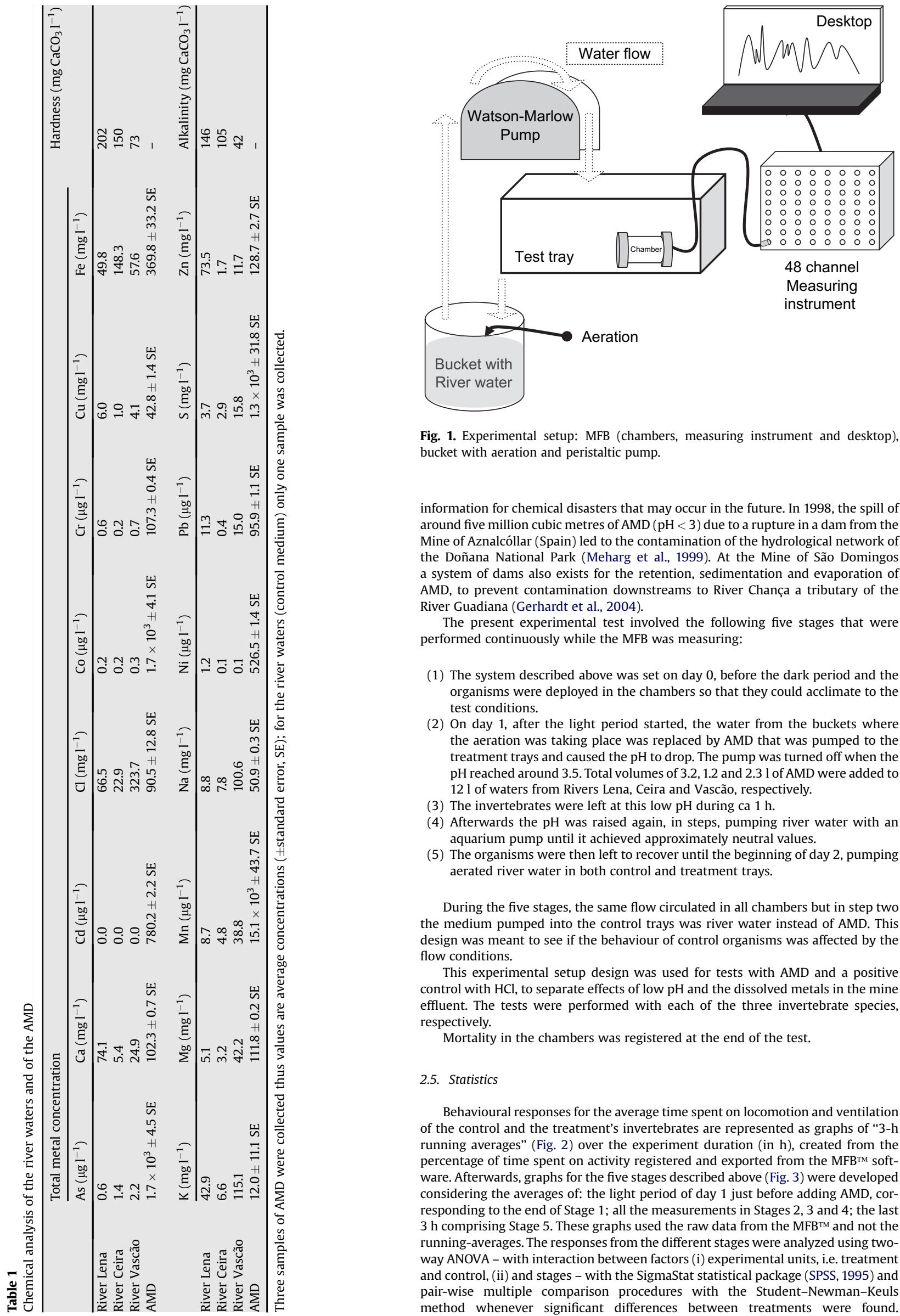

Fig. 1. Experimental setup: MFB (chambers, measuring instrument and desktop), bucket with aeration and peristaltic pump.

information for chemical disasters that may occur in the future. In 1998, the spill of around five million cubic metres of $\operatorname{AMD}(\mathrm{pH}<3)$ due to a rupture in a dam from the Mine of Aznalcóllar (Spain) led to the contamination of the hydrological network of the Doñana National Park (Meharg et al., 1999). At the Mine of São Domingos a system of dams also exists for the retention, sedimentation and evaporation of AMD, to prevent contamination downstreams to River Chança a tributary of the River Guadiana (Gerhardt et al., 2004).

The present experimental test involved the following five stages that were performed continuously while the MFB was measuring:

(1) The system described above was set on day 0 , before the dark period and the organisms were deployed in the chambers so that they could acclimate to the test conditions.

(2) On day 1, after the light period started, the water from the buckets where the aeration was taking place was replaced by AMD that was pumped to the treatment trays and caused the $\mathrm{pH}$ to drop. The pump was turned off when the $\mathrm{pH}$ reached around 3.5. Total volumes of 3.2,1.2 and 2.3 I of AMD were added to 121 of waters from Rivers Lena, Ceira and Vascão, respectively.

(3) The invertebrates were left at this low pH during ca $1 \mathrm{~h}$

(4) Afterwards the pH was raised again, in steps, pumping river water with an aquarium pump until it achieved approximately neutral values.

(5) The organisms were then left to recover until the beginning of day 2, pumping aerated river water in both control and treatment trays.

During the five stages, the same flow circulated in all chambers but in step two the medium pumped into the control trays was river water instead of AMD. This design was meant to see if the behaviour of control organisms was affected by the flow conditions.

This experimental setup design was used for tests with AMD and a positive control with $\mathrm{HCl}$, to separate effects of low $\mathrm{pH}$ and the dissolved metals in the mine effluent. The tests were performed with each of the three invertebrate species, respectively.

Mortality in the chambers was registered at the end of the test

\subsection{Statistics}

Behavioural responses for the average time spent on locomotion and ventilation of the control and the treatment's invertebrates are represented as graphs of "3-h running averages" (Fig. 2) over the experiment duration (in h), created from the percentage of time spent on activity registered and exported from the MFB ${ }^{\mathrm{TM}}$ software. Afterwards, graphs for the five stages described above (Fig. 3) were developed considering the averages of: the light period of day 1 just before adding AMD, corresponding to the end of Stage 1; all the measurements in Stages 2, 3 and 4; the last $3 \mathrm{~h}$ comprising Stage 5 . These graphs used the raw data from the MFB ${ }^{\mathrm{TM}}$ and not the running-averages. The responses from the different stages were analyzed using twoway ANOVA - with interaction between factors (i) experimental units, i.e. treatment and control, (ii) and stages - with the SigmaStat statistical package (SPSS, 1995) and pair-wise multiple comparison procedures with the Student-Newman-Keuls method whenever significant differences between treatments were found. 
a

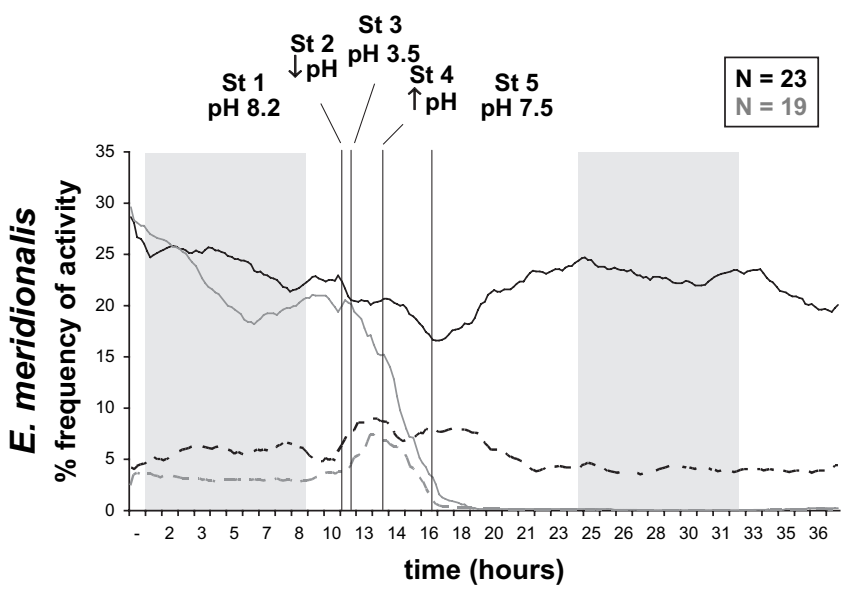

C

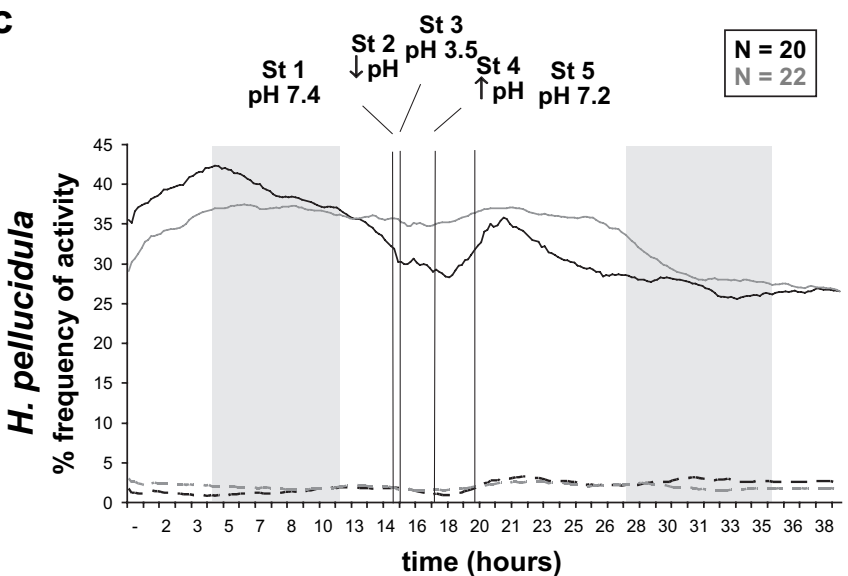

e

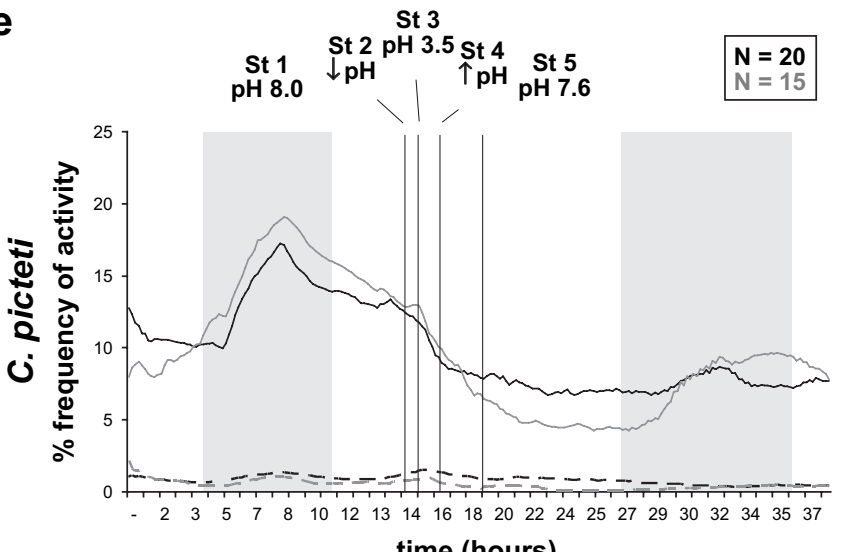

b

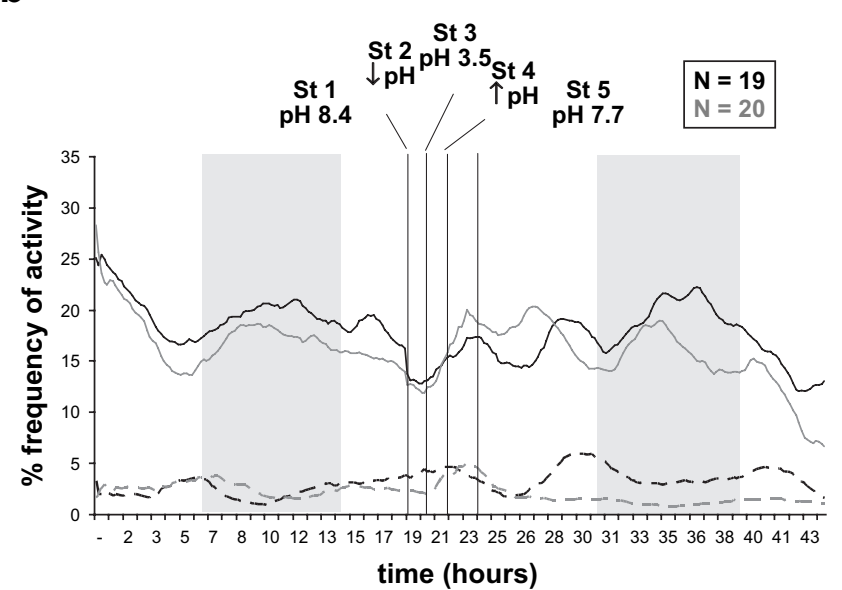

d
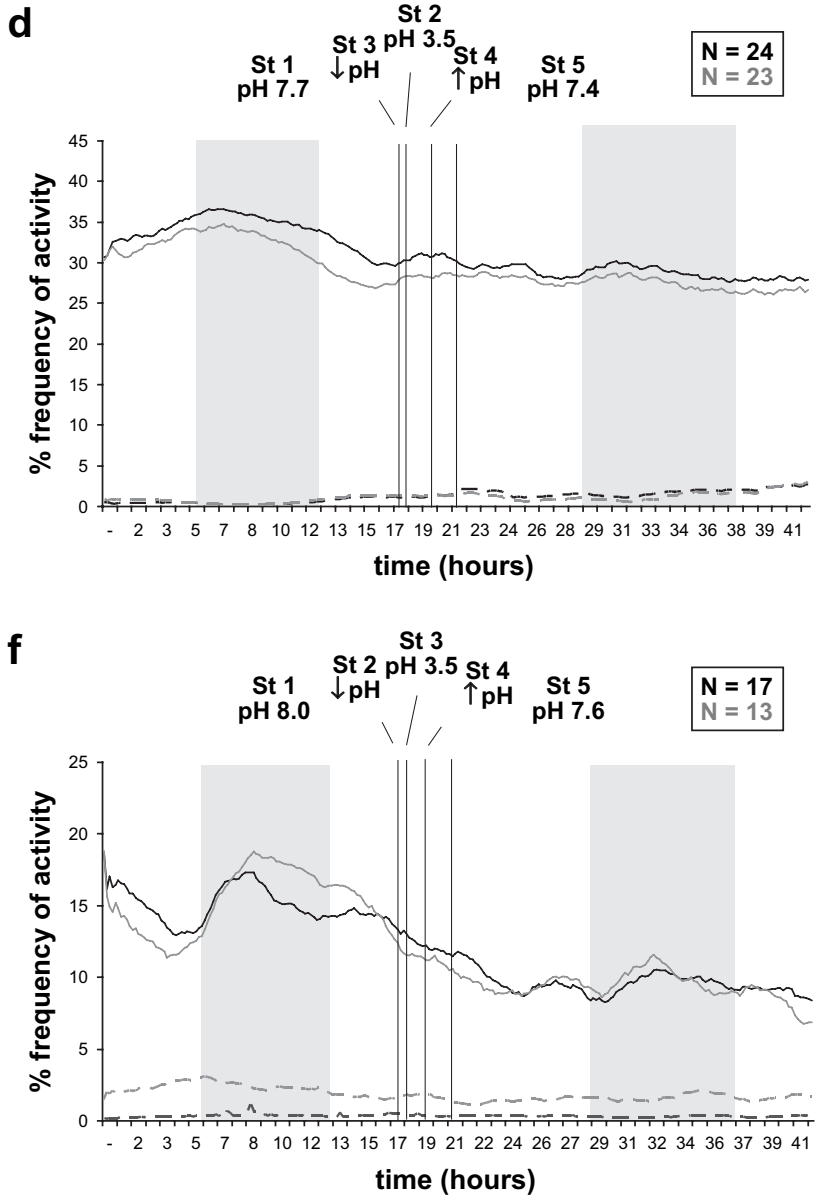

\section{Control locomotion - Treatment locomotion $\mathbf{N}=$ Control replicates \\ --- Control ventilation $\quad---$ Treatment ventilation $\mathrm{N}=$ Treatment replicates}

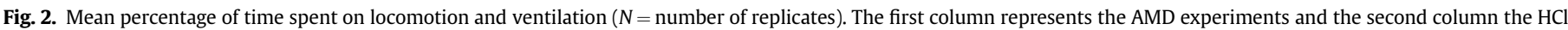

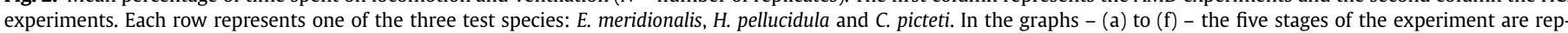

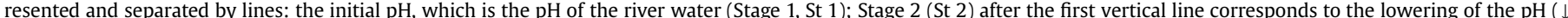

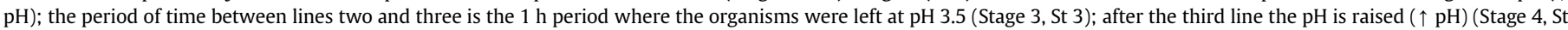
4 ); after the fourth line is the recovery period to approximately neutral pH (Stage 5, St 5). The grey shadows define the nocturnal periods.

Statistical analysis was carried out for a significance level of 0.05 . The analysis of interaction is given in Table 2. Behavioural data on the percentage of time spent on activity were arcsine transformed to ensure normality and homoscedasticity of data (Zar, 1996).
Chambers with dead organisms, and chambers with abnormal registers due to technical problems or air bubbles in the chamber were excluded from data analysis. The only exception was in the E. meridionalis exposed organisms for the AMD where the mortality was $100 \%$ and were therefore included in the graphs. 
a

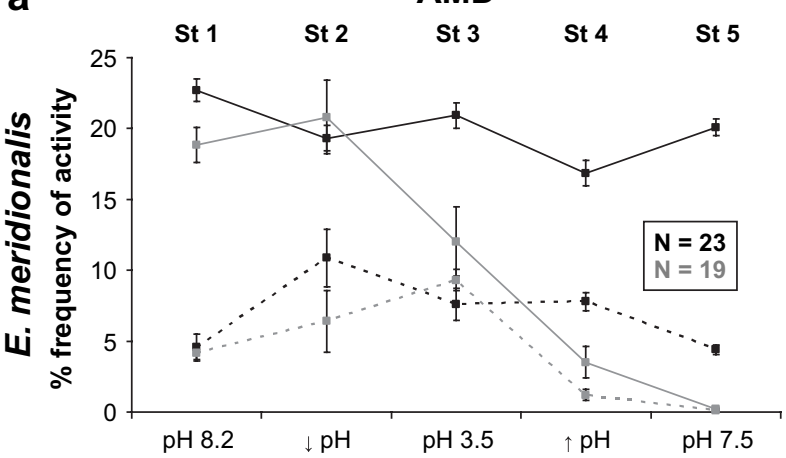

C

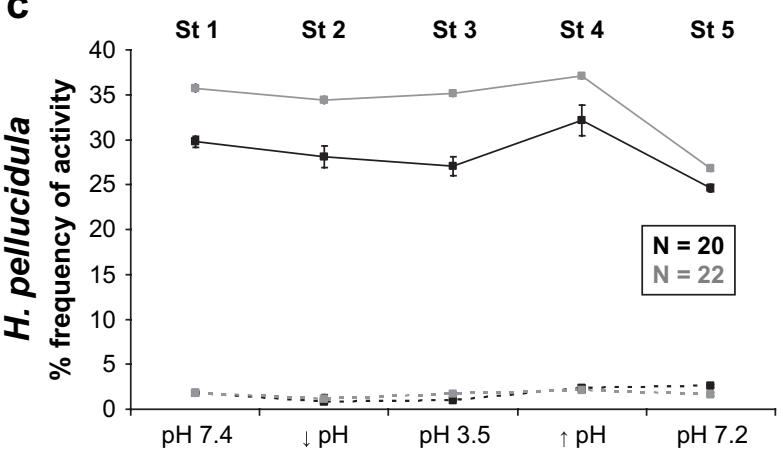

e
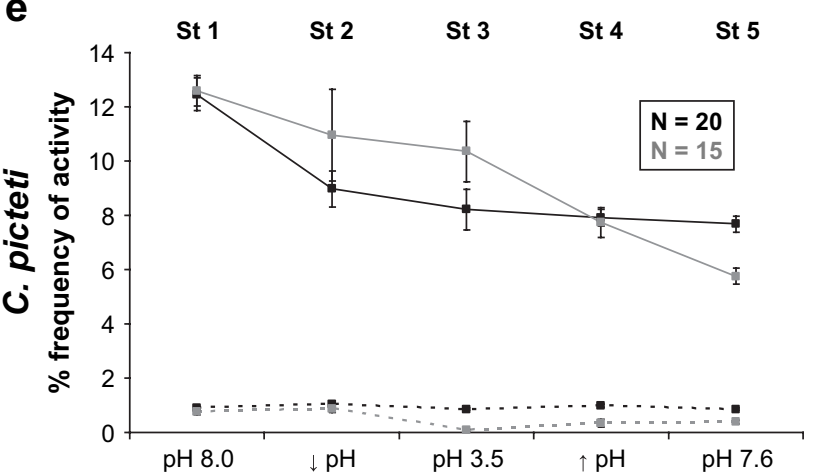

b

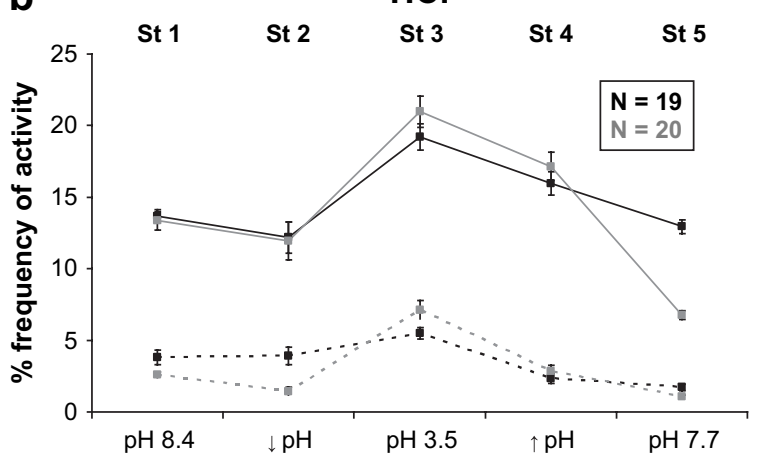

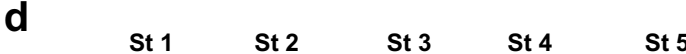

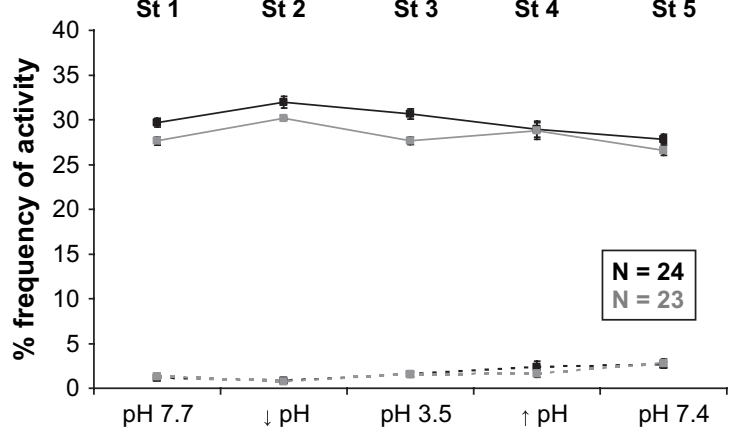

f

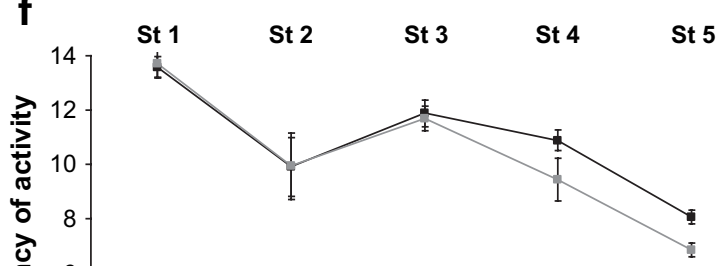

St 5

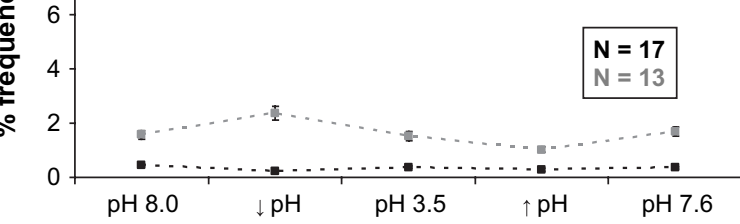

\begin{tabular}{|lll|}
\hline - Control locomotion & Treatment locomotion & $\mathrm{N}=$ Control replicates \\
- - - Control ventilation & $-\ldots-$ Treatment ventilation & $\mathrm{N}=$ Treatment replicates
\end{tabular}

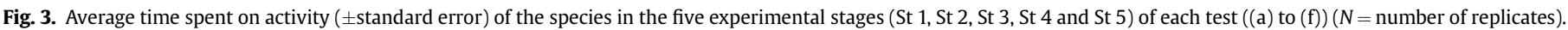

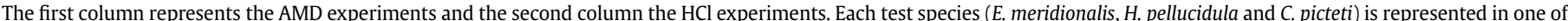
the three rows.

\section{Results}

\subsection{Chemical data}

The analysis of the total concentrations (Table 1 ) revealed higher values for the generality of metals present in AMD. The only exceptions were $\mathrm{Cl}, \mathrm{K}$ and $\mathrm{Na}$ from River Vascão and $\mathrm{K}$ from River Lena. Hardness and alkalinity are higher in River Lena, being followed by River Ceira and River Vascão.

\subsection{Behavioural data}

\subsubsection{E. meridionalis}

The AMD concentration in the treatment was so deleterious for E. meridionalis that, starting with an abrupt decrease of locomotion and ventilation when the $\mathrm{pH}$ dropped (Stage 2) (Fig. 2a), by the beginning of the recovery period (Stage 5 ) all organisms were already dead; whereas no organisms died in the control. Fig. 3a shows a clear threshold in the treatment's locomotion with

Table 2

Two-way ANOVA for the interaction between factors from the behaviour patterns: (i) experimental units, i.e. treatment and control, (ii) and stages

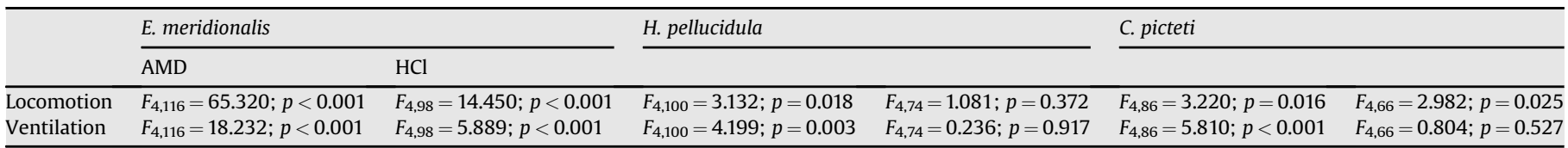

A statistically significant interaction takes place if $p<0.05$. 
a reduction from Stage 2 to Stage 3 and then to Stage 4 $\left(F_{4,116}=93.165 ; p<0.05\right)$, that showed a slight increase, not statistically significant $\left(F_{4,116}=93.165 ; p=0.635\right)$, when the $\mathrm{pH}$ started to drop. An increasing trend in the ventilation of the exposed organisms was also observed from acclimation (Stage 1) to $\mathrm{pH} 3.5$ (Stage 3 ) that doubled when the stressor effect was added (ca $5 \%$ in Stage 1 to ca $10 \%$ in Stage 3$)\left(F_{4,116}=36.253 ; p<0.05\right)$, with a clear decrease from Stage 3 to Stage $4\left(F_{4,116}=36.253 ; p<0.05\right)$. Whereas statistically significant differences between control and treatment could be observed for ventilation when lowering the $\mathrm{pH}$ $\left(F_{1,116}=73.110 ; p<0.05\right)$ (Stage 2$)$, differences in the locomotion could only be observed in Stage 3 when the $\mathrm{pH}$ remained at 3.5 $\left(F_{1,116}=217.000 ; p<0.05\right)$.

Testing the $\mathrm{pH}$ toxicity alone, with $\mathrm{HCl}$, the effect on the exposed organisms can be considered more subtle in comparison with the control. Fig. 2b shows a relative overlay of the activity curves. No mortality was observed in the exposed organisms and in the control only three specimens (8.3\%) died. As a reaction to the $\mathrm{HCl}$, at the end of the experiment (Stage 5 ) the activity of the exposed animals was much lower than that of control animals $\left(F_{1,98}=8.220 ; p<0.05\right)$.

\subsubsection{H. pellucidula}

The insect $H$. pellucidula seems to be unaffected by the effect of the AMD pulse (Fig. 2c) because no threshold in the behaviour could be observed in the exposed organisms with the drop of $\mathrm{pH}$ and no organisms died in either treatment or control. The treatment's locomotion stayed high in the first $27 \mathrm{~h}$ of the experiment and dropped to values similar to the control afterwards. The ventilation of the control and the exposed organisms remained quite stable during the entire test period. An overall trend of decrease in treatment and control locomotion was observed $\left(F_{4,100}=36.237\right.$; $p<0.05$ ) (Fig. 3c). Moreover, locomotion was higher in exposed organisms than in control $\left(F_{1,100}=68.618 ; p<0.05\right)$.

No effects were observed by the acidification of the $H$. pellucidula test medium with $\mathrm{HCl}$ in the activity and in the mortality $(0 \%$ control and treatment). The shape of the activity curves is very similar in each experiment (Fig. 2d). Except for locomotion in the period of time at $\mathrm{pH} 3.5$ no statistically significant differences between the control and the treatment activity of the insects were found (locomotion: $F_{1,74}=7.870 ; p<0.05$; ventilation: $F_{1,74}=0.143$; $p<0.05$ ) (Fig. 3d).

\subsubsection{C. picteti}

A marked similarity in the shape of the activity curves of $C$. picteti can be observed with an overall decreasing tendency of the locomotion despite its increase in the darkness periods (Fig. 2e). A $25 \%$ of the exposed organisms died whereas only $4.2 \%$ of mortality occurred in the control. The organisms responded to the AMD with significantly higher locomotion rate at low pH (Stages 2 and 3), compared to the control organisms $\left(F_{1,86}=0.0151 ; p<0.05\right)$ (Fig. 3e). By the end of the test (Stage 5), the treatment's locomotion was reduced and lower than in the control $\left(F_{1,86}=0.0151 ; p<0.05\right)$. Ventilation of the organisms also seemed to respond to the AMD with a decreased activity in relation to the controls after the period spent at pH 3.5 (beyond Stage 2$)\left(F_{1,86}=59.978 ; p<0.05\right)$.

Fig. 2f shows the same pattern of activity observed in Fig. 2e. Mortality was observed in both treatment and control organisms (respectively, 29.2\% and 20.8\%). Ventilation was higher in the control than in the treatment in all stages $\left(F_{1,66}=191.862 ; p<0.05\right)$ (Fig. 3f). A reduction of locomotion of the treatment in relation to the control after the increase of $\mathrm{pH}$ began $\left(F_{1,66}=6.033 ; p<0.05\right)$ could be observed.

\section{Discussion}

In Stage 2, AMD was introduced into the test medium with consequent entrance of heavy metals and decrease in $\mathrm{pH}$. No samples for chemical analysis were taken at $\mathrm{pH} 3.5$ but in other laboratory tests it was observed that by diluting AMD from River Lena in water, at pH 5.8, there was an increase in concentration of heavy metals such as $\mathrm{Cd}, \mathrm{Cu}$ and $\mathrm{Zn}$ of several orders of magnitude reaching values of, respectively, 17, 260 and $1641 \mathrm{~g} \mathrm{l}^{-1}$ (MacedoSousa et al., 2007). According to the biotic ligand model (Di Toro et al., 2001), the toxicity of metals in solution is dependent on their bioavailability due to complexation of metals with ligands and competition with cations for the site of toxic action on the organisms. Free ions are the most bioavailable species and are therefore more toxic. Hardness and $\mathrm{pH}$ play a major role in determining metal toxicity; by competing with heavy metal ions for the active binding sites $\mathrm{Ca}^{2+}$ cations are responsible for reducing AMD's toxic effects whereas $\mathrm{H}^{+}$ions reduce the fraction of metal complexed with carbonates. In principle, since all organisms in the present experiment are exposed to the same level of $\mathrm{pH}$ (3.5), one of the factors that can explain the difference in AMD toxicity is the speciation of metals in solution that depends on river water hardness. Table 1 shows that River Lena (where E. meridionalis were sampled) has the highest hardness and therefore would be expected to make metals less bioavailable; River Ceira (where $H$. pellucidula were sampled) can also be considered hardwater but the water from River Vascão (where $C$. picteti were sampled) is clearly less hard. Also from Table 1 , it can be observed that rivers present different alkalinities and concomitant different buffer capacity thus providing aquatic animals with different protection to the deleterious effects of $\mathrm{H}^{+}$ions. River Lena presents the highest buffer capacity being followed by Ceira and Vascão. Thus, it would be expected that the chemistry of river water would have a clear influence in the level of responses from the different species but as observed E. meridionalis, tested in the harder original river water and with the highest alkalinity, is the most sensitive invertebrate to AMD.

The toxicity of AMD is, of course, dependent on the sensitivity of the organisms. The mortality data suggested that the dose of AMD used was acutely toxic to $E$. meridionalis and to some extent toxic to C. picteti, whereas $H$. pellucidula were not affected by this isolated pulse. These results are in agreement with those obtained by (Merret et al., 1991) where mayflies were not particularly affected and hydropsychid presented an apparent lack of acid sensitivity to single simulated episodes of acidification, although repeated acid episodes may enhance these species' mortality. The $\mathrm{LC}_{50}(48 \mathrm{~h})$ of $C$. picteti exposed to AMD has been shown by Gerhardt et al. (2005b) to be at $\mathrm{pH} 4.8-4.9$, setting a $\mathrm{pH}$ unit range considerably higher than the levels tested in this work, but of course it has to be taken into account that it was a peak of low $\mathrm{pH}$ that lasted for only ca $1 \mathrm{~h}$. By contrast, Amphipods are among the most acid sensitive organisms (Økland and Økland, 1986; Herrmann, 1990) and are also very sensitive to the metals in solution, e.g. Cd (Gerhardt, 1995a), and this may explain their higher mortality rates. Macedo-Sousa et al. (2007) showed that with a concentration of AMD at a pH of 5.8, at the end of 5 days, mortality occurred in $67 \%$ of the E. meridionalis specimens. $\mathrm{HCl}$ did not seem to affect the species tested based on using mortality as an endpoint for the analysis of the effect of the low pH pulses.

The early warning responses of $E$. meridionalis were immediately after the addition of AMD and consisted of increased locomotion followed by a decrease in activity and increase in ventilation. In other lab trials using AMD concentrations at $\mathrm{pH}$ below 6.4, E. meridionalis also showed an overall reduction of the activity at the end of 5 days (Macedo-Sousa et al., 2007). The responses to $\mathrm{HCl}$ were not followed by a conspicuous threshold although the organisms responded immediately with a decrease in ventilation as soon as acidification took place.

$H$. pellucidula did not present any kind of variation in its activity alone or in relation to the control that illustrated early warning responses to the AMD. Using other endpoints, this null response 
with hydropsychidae had already been observed for other complex effluents (Pontasch and Cairns, 1991), and even with AMD (Earle and Callaghan, 1998).

No clear threshold was seen regarding $C$. picteti behavioural responses to AMD although a higher rate of locomotion could be observed in relation to the control, followed by a decrease in activity. In previous MFB tests performed with this species, there was also a decrease in locomotion with increasing AMD concentrations after $48 \mathrm{~h}$ (Gerhardt et al., 2005b). Regarding $\mathrm{HCl}$ experiments, a decrease in locomotion could be observed at the end of the test. The locomotion in $C$. picteti increased in the dark periods, correspondent to night time. This may be explained by the fact that in this species as well as in other Ephemeroptera, drifting activities take place mainly at night, with acid exposure weakening this rhythm (Gerhardt et al., 2005a), probably due to lower predation pressure (Kratz et al., 1994).

\section{Conclusions}

Following our hypothesis, it was possible to detect behavioural early warning responses in both ventilation and locomotion of benthic invertebrates exposed to a spike of AMD with the MFB ${ }^{\mathrm{TM}}$. This work has also proven that behavioural responses measured online may be included in risk assessment protocols, especially for the characterization of effects.

The following indicator species can be recommended: for sublethal exposures E. meridionalis may be a good choice as a sentinel species, whereas $C$. picteti, as a less sensitive species, may be used when acute exposures are expected.

The joint effect of the high concentration of $\mathrm{H}^{+}$and metals in solution accounted for the majority of the results observed. It is not useful to try to discover, to isolate or to rank each element in terms of toxic effects when dealing with (i) water samples from the field, containing a cocktail of substances and (ii) an automated behavioural early warning system such as that studied here because they provide an integrated response of the organisms to the whole water and do not give us quantitative or qualitative information about the pollutant.

\section{Acknowledgments}

The present work was supported by the FCT (Portuguese Science and Technology Foundation) with the Masters' Grant to Joaquim A. Macedo de Sousa (SFRH/BM/8677/2002) and Project CETERA (POCTI/BIA/10200/98/2001). The authors would like to thank Dr. Dirk Platvoet for the identification of E. meridionalis and Dr. Diego García de Jalón for the identification of $H$. pellucidula. The authors would also like to thank the anonymous referees for their comments and valuable suggestions.

\section{References}

Beitinger, T.L., 1990. Behavioral reactions for the assessment of stress in fishes. J. Great Lakes Res. 16, 495-528.

Beitinger, T.L., McCauley, R.W., 1990. Whole-animal physiological processes for the assessment of stress in fishes. J. Great Lakes Res. 16, 542-575.

Cummins, C.P., 1993. Acid solutions. In: Calow, P. (Ed.), Handbook of Ecotoxicology. Blackwell Scientific Publications, Oxford, pp. 21-44.

Depledge, M.H., Weeks, J.M., Bjerregaard, P., 1993. Heavy metals. In: Calow, P. (Ed.), Handbook of Ecotoxicology. Blackwell Scientific Publications, Oxford, pp. 79105.

Di Toro, D.M., Allen, H.E., Bergman, H.L., Meyer, J.S., Paquin, P.R., Santore, R.C., 2001. Biotic ligand model of the acute toxicity of metals. 1. Technical basis. Environ Toxicol. Chem. 20, 2383-2396.

Earle, J., Callaghan, T., 1998. Impacts of mine drainage on aquatic life, water uses, and man-made structures. In: Brady, K.B.C., Smith, M.W., Schueck, J. (Eds.), Coal Mine Drainage Prediction and Pollution Prevention in Pennsylvania. Pennsylvania's Department of Environmental Protection, Harrisburg, pp. 4.1-4.10.

Fjellheim, A., Raddum, G.G., 1990. Acid precipitation - biological monitoring of streams and lakes. Sci. Total Environ. 96, 57-66.
Gerhardt, A., 1992. Review of heavy metals on stream invertebrates with special emphasis on acid conditions. Water Air Soil Poll. 66, 289-314.

Gerhardt, A., 1993. Short term toxicity of iron ( $\mathrm{Fe})$ and lead $(\mathrm{Pb})$ to the mayfly Leptophlebia marginata (L.) (Insecta) in relation to freshwater acidification. Hydrobiologia 284, 157-168.

Gerhardt, A., 1995a. Effects of Metals on Stream Invertebrates. Department of Ecology - Chemical Ecology and Ecotoxicology, Lund University, Lund.

Gerhardt, A., 1995b. Joint and single toxicity of cadmium (Cd) and iron (Fe) related to metal uptake in the mayfly Leptophlebia marginata (L.) (Insecta: Ephemeroptera). Hydrobiologia 306, 229-240.

Gerhardt, A., 1995c. Monitoring behavioural responses to metals in Gammarus pulex (L.) (Crustacea) with impedance conversion. Environ. Sci. Pollut. Res. Int. 2, 1523.

Gerhardt, A., 1996. Behavioural early warning responses to polluted water. Environ. Sci. Pollut. Res. Int. 3, 63-70.

Gerhardt, A., 2000a. Biomonitoring for the 21st Century. In: Gerhardt, A. (Ed.), Biomonitoring of Polluted Water. Trans Tech Publications Ltd., Zürich, pp. $1-12$.

Gerhardt, A., 2000b. Recent trends in biomonitoring for water quality control. In: Gerhardt, A. (Ed.), Biomonitoring of Polluted Water. Trans Tech Publications Ltd., Zürich, pp. 95-118.

Gerhardt, A., 2001. A new multispecies freshwater biomonitor for ecologically relevant supervision of surface waters. In: Butterworth, F.M., Gunatilaka, A., Gonsebatt, M.E. (Eds.), Biomonitors and Biomarkers as Indicators of Environmental Change: a Handbook. Plenum, New York, pp. 301-307.

Gerhardt, A., Carlsson, A., Ressemann, C., Stich, K.P., 1998. New online biomonitoring system for Gammarus pulex (L.) (Crustacea): in situ test below a copper effluent in south Sweden. Environ. Sci. Technol. 32, 150-156.

Gerhardt, A., Janssens de Bisthoven, L., Penders, E., 2003. Quality control of drinking water from the River Rhine with the Multispecies Freshwater Biomonitor. Aquat. Ecosys. Health Manag. 6, 1-8.

Gerhardt, A., Janssens de Bisthoven, L., Soares, A.M.V.M., 2004. Macroinvertebrate response to acid mine drainage: community metrics and on-line behavioural toxicity bioassay. Environ. Pollut. 130, 263-274.

Gerhardt, A., Janssens de Bisthoven, L., Soares, A.M.V.M., 2005a. Effects of acid mine drainage and acidity on the activity of Choroterpes picteti (Ephemeroptera: Leptophlebiidae). Arch. Environ. Con. Tox. 48, 450-458.

Gerhardt, A., Janssens de Bisthoven, L., Soares, A.M.V.M., 2005b. Evidence for the stepwise stress model: Gambusia holbrooki and Daphnia magna under acid mine drainage and acidified reference water stress. Environ. Sci. Technol. 39, 41504158.

Gerhardt, A., Svensson, E., Clostermann, M., Fridlund, B., 1994. Monitoring of behavioral patterns of aquatic organisms with an impedance conversion technique. Environ. Int. 20, 209-219.

van der Geest, H.G., Greve, G.D., de Haas, E.M., Scheper, B.B., 1999. Survival and behavioral responses of larvae of the caddisfly Hydropsyche angustipennis to copper and diazinon. Environ. Toxicol. Chem. 18, 1965-1971.

Havas, M., 1981. Physiological response of aquatic animals to low pH. In: Singer, R. (Ed.), Effects of Acidic Precipitation on Benthos. North American Benthological Society, Hamilton, pp. 49-65.

Herrmann, J., 1990. Physiological, foodchain and ecological effects among benthic invertebrates exposed to low $\mathrm{pH}$ and associated metal concentrations. In: Mason, B.J. (Ed.), The Surface Waters Acidification Programme. Cambridge University Press, pp. 383-386.

Kratz, K.W., Cooper, S.D., Melack, J.M., 1994. Effects of single and repeated experimental acid pulses on invertebrates in a high altitude Sierra Nevada stream. Freshwater Biol. 32, 161-183.

Lagadic, L., Caquet, T., 1998. Invertebrates in testing of environmental chemicals: are they alternatives. Environ. Health Persp. 106, 593-611.

Lopes, I., Gonçalves, F., Soares, A.M.V.M., Ribeiro, R., 1999. Discriminating the ecotoxicology due to metals and to low $\mathrm{pH}$ in acid mine drainage. Ecotoxicol. Environ. Saf. 44, 207-214.

Macedo-Sousa, J.A., Pestana, J.L.T., Gerhardt, A., Nogueira, A.J.A., Soares, A.M.V. M., 2007. Behavioural and feeding responses of Echinogammarus meridionalis (Crustacea, Amphipoda) to acid mine drainage. Chemosphere 67, 1663-1670.

Maltby, L., Naylor, C., Calow, P., 1990. Effect of stress on a freshwater benthic detritivore: scope for growth in Gammarus pulex. Ecotoxicol. Environ. Saf. 19, 285291.

Meharg, A.A., Osborn, D., Pain, D.J., Sanchez, A., Naveso, M.A., 1999. A challenge to ecotoxicology and environmental chemistry: the Doñana, Spain, mining catastrophe. Environ. Toxicol. Chem. 18, 811-812.

Merret, W.J., Rutt, G.P., Weatherley, N.S., Thomas, S.P., Ormerod, S.J., 1991. The response of macroinvertebrates to low $\mathrm{pH}$ and increased aluminium concentrations in Welsh streams: multiple episodes and chronic exposure. Arch. Hydrobiol. 121, 115-125.

Økland, J., Økland, K.A., 1986. The effects of acid deposition on benthic animals in lakes and streams. Experientia 42, 471-486.

Oliveira, J.M.S., 1997. Algumas reflexões com enfoque na problemática dos riscos ambientais associados à actividade mineira. Boletim de Minas 39.

Palmer, C.G., Maart, B., Palmer, A.R., O'Keeffe, J.H., 1996. An assessment of macroinvertebrate functional feeding groups as water quality indicators in the Buffalo River, eastern Cape Province, South Africa. Hydrobiologia 318, 153-164.

Pantani, C., Pannunzio, G., De Cristofano, M., Novelli, A.A., Salvatori, M., 1997. Comparative acute toxicity of some pesticides, metals, and surfactants to 
Gammarus italicus Goedm. and Echinogammarus tibaldii Pink. and Stock (Crustacea: Amphipoda). B. Environ. Contam. Tox. 59, 963-967.

Patrick, R., Boyer, F., 1994. What are the requirements for an effective biomonitor In: Loeb, S.L., Spacie, A. (Eds.), Biological Monitoring of Aquatic Systems. Lewis Publishers, Boca Raton, pp. 23-29.

Persoone, G., Janssen, C.R., 1993. Freshwater invertebrate toxicity tests. In: Calow, P. (Ed.), Handbook of Ecotoxicology. Blackwell Scientific Publications, Oxford, pp. 51-65.

Peters, W.L. 1988. Origins of the North American Ephemeroptera fauna, especially the Leptophlebiidae. Mem. Entomol. Soc. Canada 144, 13-24.

Pontasch, K.W., Cairns Jr., J., 1991. Multispecies toxicity tests using indigenous organisms: predicting the effects of complex effluents in streams. Arch. Environ. Con. Tox. 20, 103-112.

SPSS, 1995. SigmaStat for Windows (Version 2.03), IL.
Statzner, B., Bretschko, G., 1998. Net-building of a caddis fly (Hydropsyche siltalai) Arch. Hydrobiol. 144, 87-102

Taylor, E.J., Maund, S.J., Pascoe, D., 1991. Toxicity of four common pollutants to the freshwater macroinvertebrates Chironomus riparius Meigen (Insecta: Diptera) and Gammarus pulex (L.) (Crustacea: Amphipoda). Arch. Environ. Con. Tox. 21, 371-376.

Taylor, E.J., Rees, E.M., Pascoe, D., 1994. Mortality and a drift-related response of the freshwater amphipod Gammarus pulex (L.) exposed to natural sediments, acidification and copper. Aquat. Toxicol. 29, 83-101.

Vuori, K.-M., 1993. Rapid behavioural and morphological responses of hydropsychid larvae (Trichoptera, Hydropsychidae) to sublethal cadmium exposure. Environ. Pollut. 84, 291-299.

Zar, J.H., 1996. Biostatistical Analysis. Prentice Hall International Editions, New Jersey. 